\title{
Economic Growth and Higher Education in South Asian Countries: Evidence from Econometrics
}

\author{
Nilofer Hussaini ${ }^{1}$ \\ ${ }^{1}$ Department of Professional Studies, Christ (Deemed to be University) (Central Campus), Bangalore, 560029, India \\ Correspondence: Nilofer Hussaini, Department of Professional Studies, Christ (Deemed to be University) (Central \\ Campus), Bangalore, 560029, India.
}

Received: December 15, 2019

Accepted: January 7, 2020

Online Published: January 8, 2020

doi:10.5430/ijhe.v9n2p118

URL: https://doi.org/10.5430/ijhe.v9n2p118

\begin{abstract}
South Asian economies has witnessed very slow growth over the years and the gap has widened manifold between other nations of Asia particularly East Asian nations and South Asian nations. This paper examines co-integration between the economic growth and reach of higher education in South Asian nations explaining this disparity. The research employed an econometric panel co-integration investigation to analyse the long run relationship of higher education and economic growth among these nations. The research confirmed positive long run causality between the economic growth of the South Asian nations and gross enrolment ratio of higher education. So, if the South Asian nations continue with their existing pattern of paying less attention to higher education by allocating low share of investment on it, poor human capital formation would result in growing further economic disparity between developed and South Asian nations where rich nations would remain richer and poor nations would remain poor with the gap remaining unabridged. This research will serve as an aid to policy makers, educators and financers of South Asian nations to bridge the gap between high- and low-income nations. The focus on the quantum of spending on higher education by the government will help improve the reach of tertiary education and build economic prosperity in these nations.
\end{abstract}

Keywords: higher education, south Asian nations, economic growth, co-integration

\section{Introduction}

The reach of higher education has been found to be significantly less in nations of South Asia compared to other Asian nations particularly East Asian including China, Republic of Korea, Singapore, Malaysia over the past several years. This draws our attention towards the cross-country issue of a continuous widening gap between high income $\&$ low-income nations within Asia. Does the increased access of higher education lead to a more employable and skilled human capital which contributes to enhanced productivity of the nations is an important question to answer witnessing the growing economic disparity among the Asian nations. This study is an attempt to understand any significant cointegration between variations in economic prosperity and tertiary education in South Asian nations resulting in poor human capital formation.

Economic growth has always been extremely uneven within the countries of South Asian region and between several other countries of Asian region. Though most of the Asian countries started off with low productivity in 1960's, East Asian nations such as China, Hong Kong, Singapore, Korea, have grown at a faster pace than Bangladesh, Sri Lanka, India, Nepal \& Pakistan of South Asia. Having shown different rate of economic progress the gap between South Asian and other Asian regions have widened with time. (refer table 1) 
Table 1. Per Capita GDP of South Asian \& other Asian Nations

\begin{tabular}{lcc}
\hline Region & Per capita GDP 1960(US\$) & Per capita GDP 2016(US\$) \\
\hline South Asia & & \\
Bangladesh & 99.5 & 1,736 \\
India & 91.7 & 2,016 \\
Nepal & 50.53 & 971 \\
Sri-Lanka & 138 & 4,265 \\
Pakistan & 89 & 1,527 \\
Other Asian Countries & & \\
China & 100 & 9,633 \\
Hong Kong & 429 & 48,231 \\
Malaysia & 230 & 10,704 \\
Singapore & 474 & 61230 \\
Thailand & 113 & 7,084 \\
\hline
\end{tabular}

In most of the East Asia nations, increase in human capability was the key element in achieving rapid economic growth (Drèze \& Sen, 2013). The quantity and quality of higher education which resulted in better workforce allowed these nations to adopt to more advanced production processes and techniques that in turn increased their productivity. Global Competitiveness Report, 2017 (Schwab \& Sala-i-Martín, 2017) which highlighted the importance of this mutually enforcing factor on productivity, ranked Singapore as the world's $3^{\text {rd }}$ most competitive economy and Hong Kong at $6^{\text {th }}$ out of 144 economies worldwide. South Asian countries have all been ranked poorly with India $\left(68^{\text {th }}\right)$, Sri Lanka $\left(84^{\text {th }}\right)$, Bangladesh $\left(105^{\text {th }}\right)$, Nepal $\left(108^{\text {th }}\right)$ and Pakistan $\left(110^{\text {th }}\right)$.

South Asian nations have demonstrated the weakness in human capabilities leading to a staggered growth over the years. There exist few studies assessing the similarity between the economic growth (EG) and human development (HD) trend in developed and developing economy. A two-way link between HD \& EG had been found in cross country studies of developing nations indicating linkage between higher economic growth and higher human development (Ranis, 2004). (Aturupane, Glewwe, \& Isenman, 1994) in a cross-country study examined the impact of economic growth on the social indicators and how social indicators be measured. These studies emphasized the balanced approach between EG and HD that should be adopted by the policy makers for a sustainable growth of any economy. However, these studies focused on a cross-sectional data to establish relationship on various aspects of human capital relationship such as literacy, health and standard of living with long run economic growth.

Studies on endogenous growth model highlighted the improvement of human capital by increasing the quantum of government expenditure to predict the economic growth outcome (Lucas R. E., 1988). (Ghosal, 2010) re-enforced the notion of long run economic growth through increased government spending on human capital. (Agarwal, 2015) evaluated the public expenditure policy from human development perspective and found per capita income as a significant determinant of HDI in India. In this background, we cannot deny that there is link between the investment made by the government on the human development in emerging nations particularly South Asian and the improvement in HD. But most of these studies have been focused on the overall development of the human capabilities. Limited studies only have been conducted to highlight the role of higher education in building the human capital and its long run economic growth relation.

Education has been an essential element of human development capabilities in HDI. While primary and secondary education been considered important for improving human capabilities in the past several decades, the potential of higher education in propelling the economic growth in this knowledge-based economy is being re-examined increasingly. The underlying view is that an economy with superior availability of human skills particularly in the technical and professional capacity developed by higher education is likely to have faster economic growth (Oketch, McCowan, \& Schendel, 2014). Increasing the access and reach of higher education in the economy helps to improve the human capital (Hanishek, 2016). Evidence shows high rate of return in higher education more than that of secondary education and primary education (McMahon, 1999). Some of the influential studies confirmed correlation between the rate of investment in education and development of human capital to explain the economic growth across countries (Levine \& Renelt, 1992), (Barro \& Sala-i-Martin, 2003), (Hassan \& Cooray, 2015), (Pink-Harper, 
2015), (Schultz, 1989). Developing countries fear if higher education is not adequately addressed to contribute to the changing requirements of the labour market then yet another reason for growing disparity will set in. Universities of South Asian countries which have been ranked poorly on several international ranking such as QS World University Ranking, CWUR World Ranking depicts the plight of higher education that have been under invested and neglected. (refer table 2).

Table 2. Academic Ranking of South Asian \& other Asian Universities for 2018

\begin{tabular}{lccc}
\hline & QS World University & Times Higher Education & CWUR World \\
\hline China & 25 & 27 & 92 \\
Hong Kong & 26 & 40 & 171 \\
Singapore & 11 & 22 & 173 \\
Korea & - & - & 60 \\
India & 172 & 251 & 420 \\
Pakistan & 431 & 1001 & 799 \\
Sri Lanka & 751 & 801 & - \\
Bangladesh & 701 & 1001 & - \\
\hline
\end{tabular}

Financial priority given currently in South Asian countries is much lesser than what it should be given by these nations. Though most of South Asian nations clearly state education as their priority in their national objective, they are far from allocating even 6\% share of GDP on education (other than Bhutan) as recommended by World Education Forum, UNESCO \& UNDP to develop better human capabilities. (refer table 3).

Table 3. Share of Educational Expenditure as a percentage of GDP by South Asian Countries

\begin{tabular}{lcccr}
\hline & 2014 & 2013 & 2012 & 2011 \\
\hline Nepal & 3.99 & 3.47 & - & 3.843 \\
Afghanistan & 3.67 & - & 2.52 & 3.44 \\
Sri Lanka & 1.93 & $1.62(0.34)$ & $1.50(0.28)$ & $1.81(0.32)$ \\
Pakistan & $2.47(0.55)$ & $2.49(0.80)$ & 2.141 & 2.22 \\
Myanmar & - & - & - & 0.79 \\
Bangladesh & - & 1.97 & 2.18 & $2.13(0.23)$ \\
Bhutan & $5.90(0.61)$ & $5.59(1.02)$ & - & $4.65(0.51)$ \\
India & - & 3.84 & $3.87(1.23)$ & $3.84(1.29)$ \\
\hline
\end{tabular}

Source: UNESCO, TheGlobalEconomy.com

Note: value in parenthesis shows public spending in higher education

The Asian, mainly East Asian nations that have huge economic productivity are in a position to make larger expenditure towards improvement of education such as increasing the number of institutions, improving the infrastructural facilities of institutions or making the quality of education better unlike low income nations of Asia. This results in higher enrollment in higher education and better human capital formation in those countries. Gross enrolment ratio (GER) which acts as an indicator of the overall reach of education in a country reflects the cross country disparity explicitly with nations like China, Hong Kong, Singapore showing higher GER by 2014 and the other nations such as Bangladesh, Pakistan, India, Nepal, Sri Lanka, Burma, Afghanistan \& Maldives showing relatively much lower GER over past several years when these countries were almost at same level in 2000 (refer figure no. $1 \& 2$ ). 

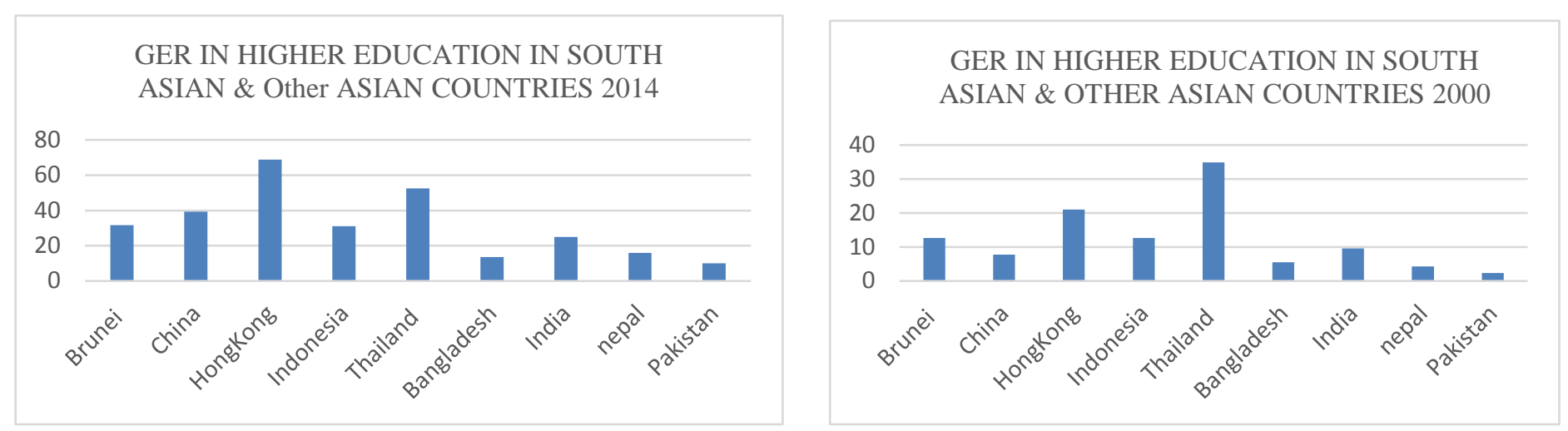

Figure 1 \& 2. GER in higher education in South Asian \& other asian countries

Fundamentally, there are two theoretical perspectives about how human capital should be measured in the area of education. (Mincer, 1970) measured human capital through enrolment ratio while (Aghion, Boustan, Hoxby, \& Vandenbussche, 2009) measured the human capital through the total actual expenditure.The focus of this paper is essentially to examine long run association between gross enrolment ratio in higher education in South Asian nations (leading to directly augmenting the higher education and improving the human capabilities) and the long run economic growth of those nations.

\section{Method}

The aim of the study to examine the long run association of the higher education on the economic growth of the Asian countries is based on the augmented Solow endogenous growth model (Mankiw, Romer, \& Weil, 1992).

$$
y(t)=K(t)^{\alpha} H(t)^{1-\alpha}
$$

Where $y=$ is output, $K(t)$ is stock of physical capital and $H(t)$ is stock of human capital. (Tallman \& Wang, 1992) suggest human capital as a function of education,

$$
H(t)=E(t)^{\varphi}
$$

where $\varnothing$ is assumed to be unity. Assuming $\mathrm{K}(\mathrm{t})$ grow at a constant and exogenous rate of $\mathrm{n}, K(t)=K(0) e^{n t}$ the function could be described in the simplest form as

$$
y(t)=E(t)
$$

To empirically establish relationship between the macro economic variables in equation above, the equation was transformed into a panel equation in which natural log values of both the variables were taken for the study. As the objective of the study was to establish long run relationship between higher education and economic growth panel co-integration among variables were established. (Engle \& Granger, 1987) showed that co-integration can be empirically useful method to model the long-term relationships.

$$
\operatorname{logPCGDP} \mathrm{tn}_{0}=\beta_{0}+\beta_{1} \log \mathrm{GER}+\mu_{\mathrm{it}}
$$

$\log \mathrm{GER}=$ Gross Enrolment Ratio in higher education, $\log$ PCGDP= GDP per capita of the selected Asian countries, $\mu=$ error term when $\mathrm{t}=1 \ldots, \mathrm{T}, \mathrm{n}=1 \ldots, \mathrm{N}$; $\mathrm{t}$ implies the number of observations over years and $\mathrm{n}$ implies the number of selected countries in South \& East Asia. To suit the study and its relevance, model was modified to accommodate only gross enrolment in higher education as the exogenous variable and GDP per capita as the dependent variable to measure economic growth of the countries. Several tests have been proposed for panel-co-integration like (Pedroni, 1995), (Kao, 1999), (Fisher, 1932) after it has been examined for stationarity. Data when stationary means they have constant mean and variance. The panel data was collected from 9 countries of South \& East Asia (N=9) for a span of 15 years $(\mathrm{T}=15)$ from 2000 to 2014 from the World Bank Report, United Nations Statistics.

\section{Results \& Discussion}

\subsection{Panel Unit Root Test}

The initial step was to examine the stationarity of the data. The data had to be I(1) stationary to proceed for panel co-integration. And for this study, common root method by Levin, lin, Chu (Levin, Lin, \& Chu, 2002) \& individual root by Im, Pesaran, Shin (Im, Pesaran, \& Shin, 2003) was adopted. 
The null hypothesis, according to LLC (Levin, Lin, \& Chu, 2002) \& Im, Pesaran, Shin (Im, Pesaran, \& Shin, 2003) was to test the stationarity of the panel data:

$$
\begin{gathered}
\mathrm{H}_{0}: \beta=1 \text { (not stationary) } \\
\mathrm{H}_{1}: \beta<1 \text { (stationary) }
\end{gathered}
$$

The output of the panel unit root test was shown in the table 4 . We find that both the variables were non-stationary at level, but after their first order difference, we can reject null hypothesis of non-stationarity at $1 \%$ significance level. In all, the variables were I (1).

Table 4. showing Unit root test with level \& $1^{\text {st }}$ difference

\begin{tabular}{lcccc}
\hline Variables & $\begin{array}{c}\text { LLC Test } \\
\text { Individual Intercept }\end{array}$ & $\begin{array}{c}\text { IPS Test } \\
\text { Individual Intercept }\end{array}$ & $\begin{array}{c}\text { LLC Test } \\
\text { Individual Intercept \& trend }\end{array}$ & $\begin{array}{c}\text { IPS Test } \\
\text { Individual Intercept \& trend }\end{array}$ \\
\hline LogPCGDP & $0.58752(0.7216)$ & $4.046(1.000)$ & $-0.4884(0.312)$ & $0.241(0.595)$ \\
SLogPCGDP & $-6.7431(0.000) *$ & $-4.301(0.000) *$ & $-6.9481(0.00) *$ & $-2.490(0.0064)$ \\
LogGER & $0.3281(0.628)$ & $3.077(1.000)$ & $1.2003(0.885)$ & $0.41898(0.922)$ \\
$\delta$ LGSDP & $-4.8007(0.000) *$ & $-3.8057(0.00) *$ & $-4.062(0.000) *$ & $-2.926(0.001) *$ \\
\hline
\end{tabular}

Note: Number in parentheses are $\mathrm{p}$ value, $*$ denotes $1 \%$ level of significance.

\subsection{Panel Johansen Co-integration Test}

Given the data as stationary at first difference, we test for the presence of co-integration as the next step. It was done using Pedroni (Engle-Granger) Johansen co-integration test.

$$
\begin{aligned}
& H_{0}: \beta=0(\text { no } c o-\text { integration }) \\
& H_{1}: \beta \neq 0(\text { co }- \text { integration })
\end{aligned}
$$

Pedroni proposes several tests for co-integration that allow for heterogeneous intercepts and trend coefficients across cross-sections (Pedroni, 1995). Out of 11 outcomes of the p values in individual intercept \& trend 6 outcomes show statistically significant values (refer table 5). If the majority $\mathrm{p}$ values are significant then the long run association-ship is satisfied. Null hypothesis of no co-integration between the two variables can be rejected at 5\% level of significance in the sampled countries. Thus, co-integration values support the existence of a panel co-integration between PCGDP and higher education.

Table 5. Johansen Cointegration Test (Pedroni)

\begin{tabular}{lc}
\hline Panel Co-integration test & Individual Intercept \& individual trend \\
\hline Within Dimension & $9.099233(0.000)^{*}$ \\
Panel v-Statistic & $1.007753(0.8432)$ \\
Panel rho-Statistic & $-0.334063(0.3692)$ \\
Panel PP-Statistic & $-2.19028(0.0143) *$ \\
Panel ADF-Statistic & \\
Weighted statistics & $5.4535(0.000)^{*}$ \\
Panel v-Statistic & $0.910641(0.8188)$ \\
Panel rho-Statistic & $-.89314(0.1859)$ \\
Panel PP-Statistic & $-2.3273(0.0100) *$ \\
Panel ADF-Statistic & \\
Between Dimension & $1.9232(0.9728)$ \\
Group rho-Statistic & $-1.6529(0.0492) *$ \\
Group PP-Statistic & $-2.3612(0.0091) *$ \\
Group ADF-Statistic & \\
\hline
\end{tabular}

Note: *denotes $5 \%$ level of significance 
Table 6. Kao Residual Cointegration Test

\begin{tabular}{lcc}
\hline & $\mathrm{t}$ statistic & Prob \\
\hline $\mathrm{ADF}$ & -2.1585 & 0.0154 \\
\hline
\end{tabular}

*denotes $5 \%$ level of significance

Table 7. Johansen Fisher Panel Co-integration Test.

\begin{tabular}{lcccc}
\hline & \multicolumn{4}{c}{ No intercept trend } \\
No. of CE(s) & Trace Test & Prob & Max-Eigen Value & Prob \\
\hline None & 48.63 & $0.001^{*}$ & 46.17 & $0.003^{*}$ \\
At most 1 & 20.65 & 0.2974 & 20.65 & 0.297 \\
\hline
\end{tabular}

Note: *denotes $1 \%$ level of significance

Table 8. Johansen Fisher Panel Co-integration Test:

\begin{tabular}{lcccc}
\hline & \multicolumn{4}{c}{ Linear Trend } \\
No. of CE(s) & Trace Test & Prob & Max-Eigen Value & Prob \\
\hline None & 47.72 & $0.002^{*}$ & 42.02 & $0.0011^{*}$ \\
At most 1 & 32.49 & 0.192 & 32.49 & 0.0192 \\
\hline
\end{tabular}

Note: *denotes $1 \%$ level of significance

Kao Residual co-integration test (Kao, 1999) established the co-integration between the two (refer table 6). Fisher Panel Co-integration Test (Fisher, 1932) conducted showed that the trace test value was larger than the Max-Eigen Value. Also, it implied the presence of at least 1 co-integration relationship between per capita GDP and gross enrolment ratio in higher education (refer table $7 \& 8$ ), thus establishing co-integration relationship. It is important to state here that the presence of co-integration do not explain the long or short run relationship between the variables. To find out the nature of relationship, the study estimated Vector Error Correction Model (VECM).

\subsection{Long Run Relationship: Vector Error Correction Model (VECM)}

VECM is conducted as a technique to establish the long run relationship between higher education and economic growth(Engle \& Granger, 1987). The estimation of error correction term (EST) was done to obtain the equation.

The result obtained (refer table 9) supported the long-term causality running from higher education to economic growth in all the selected countries of Asia. ECT shows (-) sign and probability value significant at $1 \%$ level. It establishes a long-term association between the economic growth (LOGPCGDP) and higher education (LOGGER). It indicated higher education has a significant impact on economic growth in the long-run. The target model is as follows:

$\mathrm{D}($ LOGPCGDP $)=\mathrm{C}(1) *($ LOGPCGDP $(-1) \quad+2.749330038886 *$ LOGGER $(-1) \quad-30.8473974203) \quad+$ $\mathrm{C}(2) * \mathrm{D}($ LOGPCGDP(-2)) + C(3)*D(LOGPCGDP(-2)) + C(4)*D(LOGGER(-1)) + C(5)*D(LOGGER(-2))

Table 9. VECM estimates: Least Square: Intercept (no trend) in CE

\begin{tabular}{lc}
\hline Dependent Variable & Independent Variable \\
\hline LOGPCGD & LOGGER \\
Intercept (No Trend) in data & $-0.006268(0.000) *$ \\
\hline
\end{tabular}

Note: Lag value $=2 ;$ P-value listed in parentheses $\& *$ indicates significance level of $1 \%$

\subsection{Short Run Relationship}

The null hypothesis states that there is no short run causality running from higher education to economic growth. Wald Test was conducted between lagged value of the independent variable in the coefficient diagnostic.

$$
\begin{aligned}
& \mathrm{H}_{0}: \mathrm{c}(4)=\mathrm{c}(5)=0 \\
& \mathrm{H}_{1}: \mathrm{c}(4) \neq \mathrm{c}(5) \neq 0
\end{aligned}
$$


Table 10. Wald Test

\begin{tabular}{lccc}
\hline Test Statistic & Value & Df & Probability \\
\hline Chi-Square & 3.605860 & 2 & 0.1648 \\
\hline
\end{tabular}

The result (refer table 10) is statistically insignificant at 5\% significance level. It shows that there is no short run causality between them.

The research confirms the long run dependency of economic performance of countries on higher education. The result of this study suggests the need for South Asian nations (where there is inability to bring efficiency in economic growth by its existing resources) to sharply increase the amount of focus through increased spending on higher education to quickly pace up their economic growth and be at par with the other Asian nations. The growing gap between the South Asian \& other Asian nations highlights policy framework as an important factor in determining the economic growth of a nation considering they all started off poor in 1960's. For South Asian countries to catch up with the level of development comparable to other Asian countries, a faster growth rate is required in the coming years especially policy makers to pay more attention to the human capital in driving the economic growth. It is recommended that the governing bodies controlling budgets should play a major role by allocating dis-proportionately higher finances to education in South Asian nations. If the higher education in these nations is not given the special attention it deserves and the existing pattern of spending on education continues, then the economic disparity will continue to increase and other nations would remain rich and poor nations would remain poor. The success of other Asian nations that has come hugely due to improved human capabilities could be replicated to South Asian nations by sharply increasing the higher education to bridge the economic disparity among the states.

\section{References}

Agarwal, P. (2015). Social Sector Expenditure and Human Development: Emperical Analysis of Indian States. Indian Journal of Human Development, Vol 9, No.2. https://doi.org/10.1177/0973703020150202

Aghion, P., Boustan, L., Hoxby, C., \& Vandenbussche, J. (2009). The Causal Impact of Education on Economic Growth: Evidence from U.S. Harvard University Publication. Retrieved from https://scholar.harvard.edu/files/aghion/files/causal_impact_of_education.pdf.

Aturupane, H., Glewwe, P., \& Isenman, P. (1994). Poverty, Human Development \& Growth: An Emerging Consensus. American Economic Review, 84(2), 244-249. Retrieved from www.jstor.org/stable/2117837

Barro, R., \& Sala-i-Martin, X. (2003). Economic Growth. NewYork, USA: McGraw-Hill/TheMITPress.

Drèze, J., \& Sen. (2013). An Uncertain Glory: India and its Contradictions. Princeton, NJ: Princeton University Press. https://doi.org/10.2307/j.ctt32bcbm

Engle, R. F., \& Granger, C. W. (1987). Co-Integration and Error Correction: Representation, Estimation, and Testing. Econometrica,55(2), 251-276. https://doi.org/10.2307/1913236

Fisher, R. (1932). Statistical Methods for Research Workers. Edinburgh: Oliver \& Boyd.

Ghosal, R. K. (2010). Inter-State Disparities in Economic Growth and Human Development in India during the First Decade of Reform. Business Studies, Vol.31. Retrieved from https://www.caluniv.ac.in/dj/BS-Journal/vol-31-32/inter-state.pdf

Hanishek, E. A. (2016). Will more higher education improve economic growth. Oxford Review of Economic Policy, 32(4), 538-552. doi:https://doi.org/10.1093/oxrep/grw025

Hassan, G., \& Cooray, A. (2015). Effects of male and female education on economic growth: Some evidence from Asia. Journal of Asian Economy, 97-109. https://doi.org/10.1016/j.asieco.2014.09.001

Im, K. S., Pesaran, M., \& Shin, Y. (2003). Testing for unit roots in heterogeneous panels. Journal of Econometrics, 115(1), 53-74. https://doi.org/10.1016/S0304-4076(03)00092-7

Kao, C. (1999). Spurious regression and residual-based tests for cointegration in panel dat. Journal of Econometrics, 90(1), 1-44. https://doi.org/10.1016/S0304-4076(98)00023-2

Levin, A., Lin, C.-F., \& Chu, C.-S. J. (2002). Unit root tests in Panel data: Asymptotic and Finite-Sample Properties. Journal of Econometrics, 108, 1-24. https://doi.org/10.1016/S0304-4076(01)00098-7 
Levine, R., \& Renelt, D. (1992). A Sensitivity Analysis of Cross- Country Growth Regressions. The American Economic Review, 942-963.

Lucas, R. E. (1988). On the Mechanics of Economic Development. Journal of Monetary Economics, 22(1), 3-42. https://doi.org/10.1016/0304-3932(88)90168-7

Mankiw, G. N., Romer, D., \& Weil, D. N. (1992). A Contribution To The Empirics Of Economic Growth. The Quarterly Journal of Economics. https://doi.org/10.2307/2118477

McMahon, W. (1999). Education and Development: Measuring the Social Benefits. Oxford University Press, Oxford.

Mincer, J. (1970). The Distribution of Labor Incomes: A Survey with Special Reference to the Human Capital Approach. Journal of Economic Literature, 1-26.

Oketch, M., McCowan, T., \& Schendel, R. (2014). The Impact of Tertiary Education on Development: A Rigorous Literature Review. Systematic Literature Review, Department for International Development (DFID): London.

Pedroni, P. (1995). Panel Cointegration: Asymptotic and Finite Sample Properties of Pooled Time Series Tests, with an Application to the PPP Hypothesis. Indiana University Working Papers in Economics, 95-103.

Pink-Harper, S. (2015). Educational attainment: An examination of its impact on regional economic growth. Economic Development, Vol.29, 167-179. https://doi.org/10.1177/0891242414561495

Ranis, G. (2004). Human Development and Economic Growth. Yale University Economic Growth Center Discussion Paper No. 887.

Ranjan, R., \& Chintu, A. K. (2013). An Application of Wagner's Law in the Indian Economy: 1970-71 to 2010-11. Knowledge Horizons - Economics, 5(4), 138-144.

Schultz, T. (1989). Investing in People: Schooling in Low Income Countries. Economic Education Revenue, Vol.8, 219-223.:https://doi.org/10.1016/0272-7757(82)90001-2

Schwab, K., \& Sala-i-Martín, X. (2017). The Global Competitiveness Report. Geneva: World Economic Forum.

Tallman, E. W., \& Wang, P. (1992). Human Capital Investment \& Economic Growth: New Routes in Theory Address Old Questions. Economic Review-Federal Reserve Bank of Atlanta, 1-12. 